\title{
The most common skill performances in shoot out from line 23 for elites in Field Hockey. (Analysis Study) \\ Dr/ Samir Shapaan Houta
}

Identification the effectiveness

of skillful performances in the performance of penalty shootout from the $23 \mathrm{~m}$ line for players of high levels in field hockey in four world championships (Champions Trophy Olympic Games - World Cup - Hockey World League) from (2010 to 2018), Twelve Matches playing shootout were chosen, in which 119 shootout were analyzed, A descriptive method with the survey technique was used. The present study displayed increase the effectiveness of the following variables in goal scoring in shootout (driving ball by push ; vent to direct right; push followed by Reverse sweep; shooting in the lower right, area No. (3) ,followed by the lower left area No. (9); first-time category). Moreover, the most effective positions in the performance of the shootout for research sample was applied with driving by push, direct right vent then shooting on the goal with the skill of push to bottom right of the goal and that in less than 6.12 second is more Effective in scoring goals.

\section{Introduction:}

Field Hockey is an Olympic game which acquire attention currently all over the world. Interest is increased for all sides related to this game whether, physical, technique, tactical, Psychic and mental side. In addition to many of changes in rules which regulate matches for win and reaching higher levels. Rules of field hockey and its regular modifications can control the behavior of game playing belong to skillful and tactical sides. (21:2)

International Hockey Federation cannot ignore the nature of hockey game which depends on amusing in performance. which is clearly shown through many changes related to competitions in rule of field hockey since 2011 till now, aiming in increase excitation and fun for the viewers, also keeping the ball in the field for the longest time for performance continuity and increase goals scoring. (10:4)

Furthermore, International Hockey Federation (2011) added some modifications in shoot out which used in case of match ending equal number of goals for each team, and we need to announce the winner, each team takes five Penalty Shoot-out. take a one-onone alternately against the goalkeeper

Assiut Journal For Sport Science Arts 
of the other team at $23 \mathrm{~m}$ line for reaching circle to vent goalkeeper and shooting the goal in not more than 8 seconds, and other players outside 23 m area. (24)

A coin is tossed. The team which wins the toss has the choice to take or defend the first penalty shootout. The team scoring or awarded the most goals is the winner and the competition ceases once an outright winner is determined. If an equal number of goals are scored after each team has taken five shoot-outs: a second series of five shootouts is taken with the same players. The sequence in which the attackers take the shoot-outs need not be the same as in the first series. When one team has scored or been awarded one more goal than the opposing team after each team has taken the same number of shoot-outs, not necessarily being all five shootouts, that team is the winner.

The shoot-out is completed under the following conditions: (8 seconds has elapsed- the attacker scores a goal- the attacker commits an offence- the goalkeeper commits an offence in which case the shoot-out is re-taken - the goalkeeper commits an intentional offence, in which case a penalty stroke is awarded - the ball goes out of play over the back-line or side-line).

Shootout are considered the easiest method for goal scoring as; the attacker will face the goalkeeper alone without defenders. It usually determines win of many teams, especially in final matches which end with two teams tied. (5) (10) (19)

On the other side, skills of hockey are modified and increased as a result of game development generally, in addition to changes in rule, which considered a common factor in all sports which imposes its evaluation by researcher to determine its effect on match results. $(2: 31)$

Field hockey is considered one of the sportive activities that clearly developed in technical, skill and physical side, which keep couches in continuous competition, not only in matches but also in gaining information to improve players level in national and international competitions. $(11: 61,62)(23: 3)$

So, innovated shoot out in hockey rule from line $23 \mathrm{~m}$ becomes the most common modification since 2011 instead of penalty stroke on 7 yards away from goal. Likewise, until now trainers and players are in continuous search to find out the most

Assiut Journal For Sport Science Arts 
technically and tactically behavior to be used for scoring goal. (11:61)

Field hockey is from the competitive games in which players use individual and compound skills in individual and group situations to score goal and win the match. So, researchers, couches and anyone participate in training process should find out the most perfect skillful performance for reaching the high levels.

Recording of tactical and
skillful performance during
competition is very important to analyze tactics specially in fixed situations used in matches or training to can recognize characteristics of offensive and defensive movements of player or team, detecting points of weakness in performance and its correction in the future. As the method of match analysis is not limited only on evaluation of players performance and team in matches and competitions, but also on the ability on using this method in evaluation of the same variables during training which reflect on players motivation for Success and superiority. (6:41) (14:2) (20:9), (22)

Sportive competitions become a conflict between attack and defense, as a result of this great development in offensive and defensive playing methods, there is a need to develop methods of evaluation and measurements to achieve the highest level in tactical and skillful performance. (20: 150)

Analysis using observation has a great importance which increase in all sports, as couches and players using it trying to reach top of competition. This type of observation depends on searching for the most perfect and effective methods that accurately record data about the match to can correctly express it. (15) (13) (12) (4) (22) (16)

Whereas international matches and tournaments are considered a true test of the level of players and their physical, skill and planning abilities. $(1: 37)$

and considering that penalty shootout is the key to winning in matches that are tied, many international teams have lost important tournaments such as the Olympic Games and the World Cup as a result of failure in such penalties. The importance of analyzing international matches, returns to its ability to provide information that can contribute in laying out appropriate planning for players' access to the global level.

Therefore, the researcher resorted to conducting this study 
aiming to identify the effectiveness of the skillful performances in the penalty shootout from the $23 \mathrm{~m}$ line for players of high levels in field hockey in four world championships (Champions Trophy - Olympic Games - World Cup - Hockey World League )In the period from (2010 to 2018) so that the training process can be directed and benefited during the design of training programs in order to reach high standards and win matches in field hockey.

\section{Aim of Study:}

Identification the effectiveness of skillful performances in the performance of penalty shootout from the $23 \mathrm{~m}$ line for players of high levels in field hockey in four world championships (Champions Trophy Olympic Games - World Cup - Hockey World League) from (2010 to 2018)

\section{Material and Methods:}

\section{Participants:}

Twelve Matches playing shootout were chosen in Tournaments (Champions Trophy - Olympic Games - World Cup - Hockey World League), from 2011 to 2018, during which 119 penalty strokes were studied, and the following tables $(1,2)$ show that:

Table (1)

description of the research sample

\begin{tabular}{|c|c|c|c|}
\hline \multicolumn{2}{|r|}{ Name of torment } & \multirow{2}{*}{$\begin{array}{c}\begin{array}{c}\text { No. of } \\
\text { shootout }\end{array} \\
20\end{array}$} & \multirow{2}{*}{$\begin{array}{c}\text { Match } \\
\text { Belgium*Pakistan } \\
\text { Australia*India } \\
\end{array}$} \\
\hline 1 & Rabobank Hockey Champions Trophy Breda 2018 & & \\
\hline 2 & Mens Champions Trophy London 2016 & 10 & Australia*India \\
\hline 3 & Hero Champions Trophy Bhubaneswar 2014 & 8 & Belgium* Netherlands \\
\hline 4 & Olympic Games 2016 Rio de Janeiro & 10 & Germany* Netherlands \\
\hline 5 & Hockey World Cup Bhubaneswar 2018 & 22 & $\begin{array}{l}\text { Australia* Netherlands } \\
\text { Belgium* Netherlands }\end{array}$ \\
\hline 6 & Rabobank Hockey World Cup The Hague 2014 & 7 & Spain* Netherlands \\
\hline 7 & World League Final Bhubaneswar 2017 & 22 & $\begin{array}{c}\text { Netherlands* Germany } \\
\text { Belgium* India }\end{array}$ \\
\hline 8 & World League Johannesburg (RSA) Semi-Final & 20 & $\begin{array}{l}\text { Ireland* France } \\
\text { Spain* Germany }\end{array}$ \\
\hline
\end{tabular}

Assiut Journal For Sport Science Arts 
Table (2)

Statistical description of research variables $N=119$

\begin{tabular}{|c|c|c|c|}
\hline \multirow{2}{*}{\multicolumn{2}{|c|}{ Variables }} & \multicolumn{2}{|c|}{ Statistical analysis } \\
\hline & & Frequency & $\%$ \\
\hline \multirow{3}{*}{$\begin{array}{l}\text { Driving skills with the } \\
\text { ball during a shootout }\end{array}$} & by push & 66 & 55.5 \\
\hline & By roll & 30 & 25.2 \\
\hline & by dribble & 23 & 19.3 \\
\hline \multirow{4}{*}{ Vent in the shootout } & Direct right & 42 & 35.3 \\
\hline & Direct left & 18 & 15.1 \\
\hline & $\begin{array}{l}\text { To the right, then turning to face the } \\
\text { goalkeeper with the back, then go left }\end{array}$ & 19 & 16 \\
\hline & $\begin{array}{l}\text { To the left, then turning to face the goalkeeper } \\
\text { with the back, then go right }\end{array}$ & 40 & 33.6 \\
\hline \multirow{7}{*}{$\begin{array}{l}\text { Skills used in shooting } \\
\text { the goal during shootout }\end{array}$} & Push & 37 & 31.1 \\
\hline & Flick & 12 & 10.1 \\
\hline & Scoop & 4 & 3.4 \\
\hline & Sweep shoot & 12 & 10.1 \\
\hline & Reverse Sweep & 22 & 18.5 \\
\hline & Hit & 18 & 15.1 \\
\hline & Reverse & 14 & 11.8 \\
\hline \multirow{8}{*}{$\begin{array}{c}\text { types of shooting } \\
\text { direction relative to the } \\
\text { goal }\end{array}$} & Top right (1) & 15 & 12.6 \\
\hline & Middle right (2) & 20 & 16.8 \\
\hline & Bottom right (3) & 34 & 28.6 \\
\hline & Middle centre (5) & 9 & 7.6 \\
\hline & Bottom centre (6) & 6 & 5.0 \\
\hline & Top left (7) & 9 & 7.6 \\
\hline & Middle left (8) & 10 & 8.4 \\
\hline & Bottom left (9) & 16 & 13.4 \\
\hline \multirow{2}{*}{ Time of shootout } & First time category & 67 & 56.3 \\
\hline & Second time category & 52 & 43.7 \\
\hline
\end{tabular}

Table (2) for the frequency and percentage of penalty shootout in four international tournaments shows that, driving by push is the highest frequency of $55.5 \%$, Then driving by roll $25.2 \%$, driving by dribble $19.3 \%$ while we find that the method Vent to the right is The highest frequency by $35.3 \%$ and comes in the last order, left by $15.1 \%$, also we find that the push

Assiut Journal For Sport Science Arts 
skill is the highest frequency of shooting at the goal by $31.1 \%$, and the flick skill is the least frequent with a rate of $3.4 \%$. Regarding to the place of shootout we find that area No. (3) at the bottom right is the highest frequency with a rate of $28.6 \%$, followed by area No. (2) with a rate of $16 . \%$, while area No. (6) came in the last order by $5 \%$. Regarding the time variable, we find that the first-time category was the highest frequency with a rate of $56.3 \%$. then the second time category at $43.7 \%$.

Procedures:

A descriptive method with the survey technique was used

\section{Research variables:}

In terms of the research aims, the researcher determined the skillful and tactical variables as follows:

\section{1- Drive the ball during a shootout:}

- by push

- by roll

- by dribble

\section{2- Vent in the shootout:}

- Direct right

- Direct left

- To the right, then turning to face the goalkeeper with the back, then go left

- To the left, then turning to face the goalkeeper with the back, then go right.
3- Skills used in shooting the goal during shootout:

- Push

- Flick

- scoop

- Sweep shoot

- Reverse sweep

- Hits.

- Reverse (11:65)

4- types of shooting direction relative to the goal:

- Top right (1)

- Middle right (2)

- Bottom right (3)

- Top center (4)

- Middle center (5)

- Bottom center (6)

- Top left (7)

- Middle left (8)

- Bottom left (9) (8:83)

\section{5- Time of shootout:}

Time of shootout was divided into two groups:

First time category (from 4.1 to less than or equal 6.12 second)

- Second time category (more than

6.12 to less than or equal 8 second)

1- Effectiveness of shootout (Goal - No goal)

\section{Research tools:}

1- Computer device that includes a Sony DVD player

2- CD's and DVD's where the matches research samples are copied after recording. 
3-Dartfish v.7 software motion analysis was used for its high accuracy in account of the times and the possibility of divided and follow-up times in skill performance (upto 1,000 of a second).

4-Data recording sheet that was developed through the researchers and that was organized according to the sequence of the monitored variables and situations.(appendix 1)

Validity and reliability of the data recording sheet:

The data sheet was evaluated through some experts to confirm the validity of the sheet contents. The researcher tested the reliability of the data recording sheet by using the test re- test of it after five days on 10 penalties from World League Round tow. The simple correlation factor was $(\mathrm{r}=.979 * *)$.

\section{Main study:}

penalty shootout had monitored and analyzed in Twelve matches in Tournaments (Champions Trophy Olympic Games - World Cup - Hockey World League), from 2011 to 2018, according to data recording sheet designed by the researcher. appendix
(1) Dartfish v.7 software motion analysis used to analysis 119 penalty shootout strokes by using normal motion, slow motion, frame by frame, and stop cadre.

After that the researcher was divided Time of shootout into two groups:

- First time category (from 4.1 to less than or equal 6.12 second)

- Second time category (more than 6.12 to less than or equal 8 second)

\section{Statistical analysis:}

Statistical analysis was done with SPSS software package by using mean and standard deviation. After data collection the results were statistically processed through cross tabulation for calculating the percentage and the repetitions of the efficient strokes using the following equation:

Effectiveness degree $=$

Total of the repetitions below the efficiency level $x$ the adjacent degree for the efficiency level Total number of repetitions Results and Discussion: 
Table (3)

The effectiveness of the penalty shootout according to ball driving $\mathrm{N}=119$

\begin{tabular}{c|c|c|c|c}
\hline \hline \multirow{2}{*}{$\begin{array}{c}\text { Driving skills } \\
\text { with the ball } \\
\text { during a shootout }\end{array}$} & \multirow{2}{*}{$\begin{array}{c}\text { Statistical } \\
\text { processors }\end{array}$} & \multicolumn{2}{|c|}{ Effectiveness } & \multirow{2}{*}{ Total } \\
\cline { 3 - 5 } & Goal & No goal & \\
\hline \hline \multirow{2}{*}{ by push } & Frequency & 54 & 12 & 66 \\
\cline { 2 - 5 } & $\%$ & $81.8 \%$ & $18.2 \%$ & $100.0 \%$ \\
\hline \multirow{2}{*}{ By roll } & Frequency & 9 & 21 & 30 \\
\cline { 2 - 5 } & $\%$ & $30.0 \%$ & $70.0 \%$ & $100.0 \%$ \\
\hline \multirow{2}{*}{ by dribble } & Frequency & 4 & 19 & 23 \\
\cline { 2 - 5 } & $\%$ & $17.4 \%$ & $82.6 \%$ & $100.0 \%$ \\
\hline \multirow{2}{*}{ Total } & Frequency & 67 & 52 & 119 \\
\cline { 2 - 5 } & $\%$ & $56.3 \%$ & $43.7 \%$ & $100.0 \%$ \\
\hline \hline
\end{tabular}

Table No. regarding the effectiveness of the penalty shootout according to ball driving increase in the effectiveness of driving by push in the scoring of goals by repeating (54) goals and a percentage of $(81.8 \%)$, followed by driving by roll repeatedly (9) goals and then driving by dribble repeatedly (4) Goals

The researcher attributes these results to the fact that the players prefer the push method because it gives a greater chance to see the field and gain empty spaces faster than the methods of rolling and dribble because the performance of the penalty shoot according to the method specified by the rule is only 8 seconds, so we find that the player needs to cut the distance from the $23 \mathrm{~m}$ line to enter the circle as soon as possible, and this confirms that the research sample teams used the method of driving with dribble (23) Time only out of 119 shoots as, this method takes longer in the empty spaces and it is preferable to use it in deception and passing by the opponent. These results are consistent with what was indicated by Abdullah.M. A (2006) that the method of driving with dribble is one of the skills that are favored to players, as it is used in camouflage and vent to the opponent and the player who has this skill, has a good movement in the field, avoid monitoring the defense and entering the circle to shoot the goal, but It is not recommended to be used except in times of need because it is considered the slowest method to drive the ball against to push and roll. $(3: 242,242)$ 
Table (4)

The effectiveness of the penalty shootout according to method of vent $N=119$

\begin{tabular}{|c|c|c|c|c|}
\hline \multirow{2}{*}{ Vent in the shootout } & \multirow{2}{*}{$\begin{array}{l}\text { Statistical } \\
\text { processors }\end{array}$} & \multicolumn{2}{|c|}{$\overline{\text { Effectiveness }}$} & \multirow{2}{*}{ Total } \\
\hline & & goal & No goal & \\
\hline \multirow[b]{2}{*}{ Direct rig } & Frequency & 35 & $\overline{7}$ & 42 \\
\hline & $\%$ & $83.3 \%$ & $16.7 \%$ & $100.0 \%$ \\
\hline \multirow{2}{*}{ Direct right } & Frequency & 12 & 6 & 18 \\
\hline & $\%$ & $66.7 \%$ & $33.3 \%$ & $100.0 \%$ \\
\hline \multirow{2}{*}{$\begin{array}{l}\text { To the right, then turning to face the } \\
\text { goalkeeper with the back, then go left }\end{array}$} & Frequency & 4 & 15 & 19 \\
\hline & $\%$ & $21.1 \%$ & $78.9 \%$ & $100.0 \%$ \\
\hline \multirow{2}{*}{$\begin{array}{c}\text { To the left, then turning to face the } \\
\text { goalkeeper with the back, then go } \\
\text { right }\end{array}$} & Frequency & 16 & 24 & 40 \\
\hline & $\%$ & $40.0 \%$ & $60.0 \%$ & $100.0 \%$ \\
\hline \multirow{2}{*}{ Total } & Frequency & 67 & 52 & 119 \\
\hline & $\%$ & $56.3 \%$ & $43.7 \%$ & $100.0 \%$ \\
\hline $\begin{array}{l}\text { Table No. (4), regarding the } \\
\text { effectiveness of the penalty shootout } \\
\text { according to the vent method shows } \\
\text { the high effectiveness of vent to the } \\
\text { direct right in scoring goals, by } \\
\text { repeating (35) goals and a percentage } \\
\text { of (83.3\%), followed by vent to the } \\
\text { left, then turning to face the goal } \\
\text { keeper with back, then directing to the } \\
\text { right repeatedly (16) A goal, then vent } \\
\text { to the left directly by repeating (12) } \\
\text { goals, and finally vent to the right, then } \\
\text { turning to face the goalkeeper with } \\
\text { back, then to left with repeated (4) } \\
\text { goals. }\end{array}$ & \multicolumn{4}{|c|}{$\begin{array}{l}\text { after performing this type of vent, the } \\
\text { player will be in a flat-faced shot } \\
\text { position because the ball will be on his } \\
\text { right and it enables him to shoot by } \\
\text { push or sweep shoot, and these skills } \\
\text { are more effective, according to the } \\
\text { results of Table No. (5), On the other } \\
\text { hand, shooting to the right of the } \\
\text { attacking player and the left of the } \\
\text { goalkeeper is more effective because } \\
\text { the goalkeeper in this case defends } \\
\text { with his hand not holding the stick, so } \\
\text { a better chance to score goal and also } \\
\text { the shooting from this method helps in } \\
\text { time reducing. }\end{array}$} \\
\hline
\end{tabular}

The researcher explains the high effectiveness of vent to direct right, as 
Table (5)

The effectiveness of the penalty shootout according to Skills used in shooting the goal $\mathbf{N}=119$

\begin{tabular}{c|c|c|c|c}
\hline \hline \multirow{2}{*}{$\begin{array}{c}\text { Skills used in } \\
\text { shooting the goal } \\
\text { during shootout }\end{array}$} & \multirow{2}{*}{$\begin{array}{c}\text { Statistical } \\
\text { processors }\end{array}$} & \multicolumn{2}{|c|}{ Effectiveness } & \multirow{2}{*}{ Total } \\
\cline { 3 - 5 } & & Goal & \multirow{2}{*}{ No goal } & \\
\hline \hline \multirow{2}{*}{ Push } & Frequency & 35 & 2 & 37 \\
\cline { 2 - 5 } & $\%$ & $94.6 \%$ & $5.4 \%$ & $100.0 \%$ \\
\hline \multirow{2}{*}{ Flick } & Frequency & 8 & 4 & 12 \\
\cline { 2 - 5 } & $\%$ & $66.7 \%$ & $33.3 \%$ & $100.0 \%$ \\
\hline \multirow{2}{*}{ Scoop } & Frequency & 0 & 4 & 4 \\
\cline { 2 - 5 } & $\%$ & $0.0 \%$ & $100.0 \%$ & $100.0 \%$ \\
\hline \multirow{2}{*}{ Sweep shoot } & Frequency & 9 & 3 & 12 \\
\cline { 2 - 5 } & $\%$ & $75.0 \%$ & $25.0 \%$ & $100.0 \%$ \\
\hline \multirow{2}{*}{ Reverse Sweep } & Frequency & 15 & 7 & 22 \\
\cline { 2 - 5 } & $\%$ & $68.2 \%$ & $31.8 \%$ & $100.0 \%$ \\
\hline \multirow{2}{*}{ Hit } & Frequency & 0 & 18 & 18 \\
\cline { 2 - 5 } & $\%$ & $0.0 \%$ & $100.0 \%$ & $100.0 \%$ \\
\hline \multirow{2}{*}{ Total } & Frequency & 0 & 14 & 14 \\
\cline { 2 - 5 } & $\%$ & $0.0 \%$ & $100.0 \%$ & $100.0 \%$ \\
\cline { 2 - 5 } & Frequency & 67 & 52 & 119 \\
\hline \hline
\end{tabular}

Table No. (5) regarding the effectiveness of the penalty shootout according to the skill used in shooting, displayed the increase in the effectiveness of the shot with the skill of push, with the repetition of (35) goals and a percentage of $(94.6 \%)$, followed by Reverse sweep with the repetition of (15) goals, while we find that the skills Hitting, reverse, flick did not achieve any effectiveness in scoring goals.

Assiut Journal For Sport Science Arts
The researcher explains increase the effectiveness of push in shooting during the shootout in Table No. (5) that it is more accurate and powerful in short distances and the player can control the ball easily and facilitate its direction to it to the place of shooting in addition to that in this skill the stick is adjacent to the ball, the opportunity Losing the ball from the attacking player is weak, unlike other skills.

This is confirmed by Abdullah.M. A(2006) and Farag.E. 
W (2008) that the skill of push is one of the most common skills used in hockey in passing and one of the most important skills in shooting on the goal because the ball is launched from the stick and the difficulty of predicting its movement

path.

\section{(3:246) (9:85)}

Table No. (5) showed that Reverse sweep came in the next order in terms of scoring goals, while we find that the two skills of sweep and reverse sweep did not achieve any effectiveness in goal scoring.

Table (6)

The effectiveness of the penalty shootout according to types of shooting direction relative to the goal $\mathrm{N}=119$

\begin{tabular}{|c|c|c|c|c|}
\hline \multirow{2}{*}{$\begin{array}{l}\text { types of shooting direction } \\
\text { relative to the goal }\end{array}$} & \multirow{2}{*}{$\begin{array}{l}\text { Statistical } \\
\text { processors }\end{array}$} & \multicolumn{2}{|c|}{ Effectiveness } & \multirow{2}{*}{ Total } \\
\hline & & Goal & No goal & \\
\hline \multirow{2}{*}{ Top right (1) } & Frequency & 9 & 6 & 15 \\
\hline & $\%$ & $60.0 \%$ & $40.0 \%$ & $100.0 \%$ \\
\hline \multirow{2}{*}{ Middle right (2) } & Frequency & 4 & 16 & 20 \\
\hline & $\%$ & $20.0 \%$ & $80.0 \%$ & $100.0 \%$ \\
\hline \multirow{2}{*}{ Bottom right (3) } & Frequency & 29 & 5 & 34 \\
\hline & $\%$ & $85.3 \%$ & $14.7 \%$ & $100.0 \%$ \\
\hline \multirow{2}{*}{ Middle centre (5) } & Frequency & 1 & 8 & 9 \\
\hline & $\%$ & $11.1 \%$ & $88.9 \%$ & $100.0 \%$ \\
\hline \multirow{2}{*}{ Bottom centre (6) } & Frequency & 5 & 1 & 6 \\
\hline & $\%$ & $83.3 \%$ & $16.7 \%$ & $100.0 \%$ \\
\hline \multirow{2}{*}{ Top left (7) } & Frequency & 6 & 3 & 9 \\
\hline & $\%$ & $66.7 \%$ & $33.3 \%$ & $100.0 \%$ \\
\hline \multirow{2}{*}{ Middle left (8) } & Frequency & 0 & 10 & 10 \\
\hline & $\%$ & $0.0 \%$ & $100.0 \%$ & $100.0 \%$ \\
\hline \multirow{2}{*}{ Bottom left (9) } & Frequency & 13 & 3 & 16 \\
\hline & $\%$ & $81.3 \%$ & $18.8 \%$ & $100.0 \%$ \\
\hline \multirow{2}{*}{ Total } & Frequency & 67 & 52 & 119 \\
\hline & $\%$ & $56.3 \%$ & $43.7 \%$ & $100.0 \%$ \\
\hline
\end{tabular}

Assiut Journal For Sport Science Arts
Researcher return that to players prefer to sweep due to its power and speed, as well as the chance of hit the ball, is more because the stick is lying on the ground and not perpendicular, and this is confirmed by Erwan. P etal (2019) (8)

El-Shahat.M.M (2003) and Abdullah.M. A(2006) showed that when the attacker shooting with reverse skills on the goal the defender does not expect it, and it comes as a surprise to the defenders and the goalkeeper. (7:119) (3:321) 
Table No. regarding the effectiveness of the shootout according to the place of shooting in the goal shows increase the effectiveness of shooting in the lower right, area No. (3) by repeating (29) goals and a percentage of $(85.3 \%)$, followed by the lower left area No. (9) repeatedly (13) A goal, while we find that the middleleft shooting, area No. (8), and area No. (5), the middle center, are less effective in scoring goals. Also, we find that area No. (4) was not used permanently to shoot on the goal while performing shootout.

The researcher attributes the increase in effectiveness of shootout in area (3) at the bottom right of the goal and area number (9) at the bottom left, as the hockey game has a special nature in terms of the goalkeeper's equipment and tools, which differs from other games in terms of free $(18: 36)(19: 154)$ movement, so we find that goalkeeper's opportunity is in Blocking the balls in the middle level is larger than the ground balls and balls in higher corners of the goal, due to the equipment that he wears and that works to obstruct him. This is clear in the decreased shooting in area No. (2) middle of the right, area No. (8) middle of the left and area No. (5) the middle center which is the place of the goalkeeper. In addition to the goalkeeper defends with his gloves only with his left hand without stick in the right goal corner and defend with a gloves and stick with his right hand in the left goal corner of the attacking player, the opportunity to score goal is higher at the right of the goal is for the attacking player, and this is confirmed by Rikky. R, Angga M. (2018): Pribadi. Y, Kontruksi (2005)

Table (7)

The effectiveness of the penalty shootout according to Time of shootout $N=119$

\begin{tabular}{c|c|c|c|c}
\hline \hline \multirow{2}{*}{ Time of shootout } & Statistical & \multicolumn{2}{|c|}{ Effectiveness } & \multirow{2}{*}{ Total } \\
\cline { 3 - 4 } & processors & goal & No goal & \\
\hline \hline First time category (from 4.1 to & Frequency & 54 & 4 & 58 \\
\cline { 3 - 5 } less than or equal 6.12 second) & $\%$ & $93.1 \%$ & $6.9 \%$ & $100.0 \%$ \\
\hline \multirow{2}{*}{$\begin{array}{c}\text { Second time category (more than } \\
6.12 \text { to less than or equal 8 second) }\end{array}$} & Frequency & 13 & 48 & 61 \\
\cline { 2 - 4 } & $\%$ & $21.3 \%$ & $78.7 \%$ & $100.0 \%$ \\
\hline Total & Frequency & 67 & 52 & 119 \\
\cline { 2 - 4 } & $\%$ & $56.3 \%$ & $43.7 \%$ & $100.0 \%$ \\
\hline \hline
\end{tabular}

Table No. (7) regarding the effectiveness of the penalty shootout according to the performance time shows increasing effectiveness of the

Assiut Journal For Sport Science Arts 
first-time category, where (54) goals were scored against (15) goals only in the second time category.

The researcher attributes the high effectiveness of the first-time category in goal scoring to the fact that, when the speed of offensive performance increase, so the chance in position success will increase, and become unexpected for the opponent resulting in scoring goals.

Hassan .I.H, Badr .M.A (2016), (Metwally, 2013) mentions

Table (8)

The most and least effective positions in performing the shootout of the research sample

\begin{tabular}{|c|c|c|c|c|c|c|c|c|}
\hline \multirow[b]{2}{*}{ Position } & \multirow{2}{*}{$\begin{array}{c}\text { Driving } \\
\text { skills } \\
\text { with } \\
\text { the ball }\end{array}$} & \multirow[b]{2}{*}{$\begin{array}{c}\text { Types of } \\
\text { vent }\end{array}$} & \multirow{2}{*}{$\begin{array}{c}\text { Skills } \\
\text { used in } \\
\text { shooting } \\
\text { at a goal }\end{array}$} & \multirow{2}{*}{$\begin{array}{c}\text { types of } \\
\text { shooting } \\
\text { direction } \\
\text { relative to } \\
\text { the goal }\end{array}$} & \multirow[b]{2}{*}{$\begin{array}{c}\text { Time of } \\
\text { shootout }\end{array}$} & \multicolumn{2}{|c|}{ Frequency } & \multirow[b]{2}{*}{ Effectiveness } \\
\hline & & & & & & goal & $\begin{array}{l}\text { No } \\
\text { goal }\end{array}$ & \\
\hline No (1) & $\begin{array}{c}\text { By } \\
\text { push }\end{array}$ & Direct right & Push & $\begin{array}{l}\text { Bottom } \\
\text { right (3) }\end{array}$ & $\begin{array}{c}\text { First } \\
\text { time } \\
\text { category }\end{array}$ & 12 & 0 & $\% 80$ \\
\hline No (2) & $\begin{array}{c}\text { By } \\
\text { push }\end{array}$ & Direct left & $\begin{array}{l}\text { Reverse } \\
\text { Sweep }\end{array}$ & $\begin{array}{l}\text { Bottom } \\
\text { left (9) }\end{array}$ & $\begin{array}{c}\text { First } \\
\text { time } \\
\text { category }\end{array}$ & 5 & 0 & $\% 100$ \\
\hline No (3) & $\begin{array}{l}\text { By } \\
\text { push }\end{array}$ & $\begin{array}{l}\text { To the left, } \\
\text { then turning to } \\
\text { face the } \\
\text { goalkeeper } \\
\text { with the back, } \\
\text { then go right }\end{array}$ & Push & $\begin{array}{l}\text { Bottom } \\
\text { right (3) }\end{array}$ & $\begin{array}{c}\text { First } \\
\text { time } \\
\text { category }\end{array}$ & 3 & 0 & $\% 100$ \\
\hline No (4) & $\begin{array}{l}\text { By } \\
\text { push }\end{array}$ & $\begin{array}{l}\text { To the left, } \\
\text { then turning to } \\
\text { face the } \\
\text { goalkeeper } \\
\text { with the back, } \\
\text { then go right }\end{array}$ & Push & $\begin{array}{r}\text { Bottom } \\
\text { center (6) }\end{array}$ & $\begin{array}{c}\text { First } \\
\text { time } \\
\text { category }\end{array}$ & 3 & 0 & $\% 100$ \\
\hline No (5) & By roll & Direct left & $\begin{array}{l}\text { Reverse } \\
\text { Sweep }\end{array}$ & $\begin{array}{l}\text { Bottom } \\
\text { left (9) }\end{array}$ & $\begin{array}{c}\text { First } \\
\text { time } \\
\text { category }\end{array}$ & 3 & 0 & $\% 100$ \\
\hline
\end{tabular}

Assiut Journal For Sport Science Arts that the player's speed and his ability to deceive the goalkeeper in a short time helps in the success of completing the penalty shootout in an ideal way and scoring a goal. Time is considered one of the most important factors affecting the total unite of skill performance,so its not only affects on kinematic of physical excersise ,but also interfer to large extent in detection of final sportive result. (11) (17) 
Follow Table (8)

The most and least effective positions in performing the shootout of the research sample

\begin{tabular}{|c|c|c|c|c|c|c|c|c|}
\hline \multirow[b]{2}{*}{ Position } & \multirow{2}{*}{$\begin{array}{c}\text { Driving } \\
\text { skills } \\
\text { with } \\
\text { the ball }\end{array}$} & \multirow{2}{*}{$\begin{array}{c}\text { Types of } \\
\text { vent }\end{array}$} & \multirow{2}{*}{$\begin{array}{c}\text { Skills } \\
\text { used in } \\
\text { shooting } \\
\text { at a goal }\end{array}$} & \multirow{2}{*}{$\begin{array}{l}\text { types of } \\
\text { shooting } \\
\text { direction } \\
\text { relative to } \\
\text { the goal }\end{array}$} & \multirow{2}{*}{$\begin{array}{l}\text { Time of } \\
\text { shootout }\end{array}$} & \multicolumn{2}{|c|}{ Frequency } & \multirow[b]{2}{*}{ Effectivenes } \\
\hline & & & & & & goal & $\begin{array}{l}\text { No } \\
\text { goal }\end{array}$ & \\
\hline No (6) & By roll & $\begin{array}{l}\text { To the left, } \\
\text { then turning } \\
\text { to face the } \\
\text { goalkeeper } \\
\text { with the } \\
\text { back, then go } \\
\text { right }\end{array}$ & Hit & $\begin{array}{l}\text { Middle } \\
\text { right (2) }\end{array}$ & $\begin{array}{l}\text { second } \\
\text { time } \\
\text { category }\end{array}$ & 0 & 7 & 0 \\
\hline No (7) & By roll & $\begin{array}{c}\text { To the right, } \\
\text { then turning } \\
\text { to face the } \\
\text { goalkeeper } \\
\text { with the } \\
\text { back, then go } \\
\text { left }\end{array}$ & Reverse & $\begin{array}{l}\text { Middle } \\
\text { left (8) }\end{array}$ & $\begin{array}{l}\text { second } \\
\text { time } \\
\text { category }\end{array}$ & 0 & 5 & 0 \\
\hline No (8) & $\begin{array}{c}\text { By } \\
\text { dribble }\end{array}$ & $\begin{array}{l}\text { To the right, } \\
\text { then turning } \\
\text { to face the } \\
\text { goalkeeper } \\
\text { with the } \\
\text { back, then go } \\
\text { left }\end{array}$ & Reverse & $\begin{array}{l}\text { Middle } \\
\text { left (8) }\end{array}$ & $\begin{array}{l}\text { Second } \\
\text { time } \\
\text { category }\end{array}$ & 0 & 4 & 0 \\
\hline
\end{tabular}

It is clear from Table No. (8) for the most and least effective positions in the performance of the shootout for research sample that when shootout is performed using driving by push and direct right vent and then shooting on the goal with the skill of push to bottom right of the goal and that in less than 6.12 second is more Effective in scoring goals, followed by position No. (2), then positions (3, 4, and 5) at the same degree, as it is clear from the table also that positions No. $(6,7,8)$ are ineffective in scoring goals.

The researcher attributes the high effectiveness of Position No. (1) in the 
performance of shootout to the fact that the research sample used the skill of ball driving by push, which is the best and most effective method of driving according to the results of Table (3). Also, direct right vent was used which considered the best type of vent according to table (4), more that we find that this position used push in shooting to bottom right of the goal in less than 6.12 second, these variables are more effective than others according to tables (5) (6) (7).

\section{Conclusion:}

Based on the research finding in four world championships (Champions Trophy - Olympic Games - World Cup - Hockey World League) from (2010 to 2018), The present study displayed increase the effectiveness of the following variables in goal scoring in shootout (driving ball by push; vent to direct right; push followed by Reverse sweep; shooting in the lower right, area No. (3) ,followed by the lower left area No. (9); first-time category from 4.1 to less than or equal 6.12 second ). Moreover, the most effective positions in the performance of the shootout for research sample was applied with driving by push, direct right vent then shooting on the goal with the skill of push to bottom right of the goal and that in less than 6.12 second is more Effective in scoring goals.

the present study depicted strategies with a high success rate of goal in elite hockey penalty shootout situation, which need further application on national players, and we need similar studied on free hits.

\section{References:}

1- Abdel Hakim.K. M(2009): Badminton between study and application, Dar Al-Wafa, Alexandria.

2- Abdel-Moati.S. A (1999) : Effect of the offside rule canceling on the effectiveness of some variables in field hockey matches, Master Thesis, faculty of Physical Education for Boys, Helwan University.

3- Abdullah.M. A (2006): Comprehensive preparation for hockey players, Ayat Center for Printing and Publishing, Zagazig.

4- Ariff, M., Norasrudin, S., Rahmat, A., \& Shariman, I. (2015) ： Passing sequences towards field goals and penalty corners in men's field hockey. J. Hum. Sport Exerc., 10(Proc2),p. 638-647.

5- Ausiie Sport Coaching Program (1991): Level 1 Coaching Manual. Australia: Tecprin. 
6-Darwish. I. T (2000): Effect of tactical Defense Formations on Volleyball Results, Master Thesis, Faculty of Physical Education, Tanta University.

7-El-Shahat.M.M (2003): Theory and practice in Field Hockey, $3^{\text {rd }}$ edition, Dar Al-Furqan, Mansoura.

8- Erwan. P , Nining. W, Yusuf. F (2019): Analysis of Biomechanics Slap Hit And Push In The Field hockey, Proceedings of the 2nd International Conference on Sports Sciences and Health 2018 (2nd ICSSH 2018).

9-Farag.E. W (2008): Field Hockey, Scientific and Training Foundations, Dar Al Maarif for Publishing, Alexandria.

10- FIH (2014): Rules of Hockey including explanations, Lausanne Switzerland, p: 4.

11-Hassan .I.H, Badr .M.A (2016): The Impact of a Training Program to Improve the Effectiveness of Performance in Shootout from the $23 \mathrm{~m}$ Line in Field Hockey, Published Research, Journal of Sports Science Applications, Issue Eighty-Eight, faculty of Physical Education for men Alexandria University.

12- Hughes, M., \& Bartlett, R. (2002):: The use of performance indicators in performance
analysis.Journal of Sports Sciences, 20(10), pp.739-754.

13- Hughes, Mike. (2004): Performance analysis-a 2004 perspective. International Journal of Performance Analysis in Sport, 4(1), 103-109.

14- Jeheon. M , Jongchul .P, Keonwook.K (2018): Analysis of the penalty corner attack strategy in international women's hockey: 2016 Champions Trophy and 2016 Olympic Games in Rio de Janeiro, Human Movement ,19(3): 82-87.

15- John S. Croucher (1998):

Statistics in sport, Australia.

16- Lythe, John. (2008) ： The physical demands of elite men's field hockey and the effects of differing substitution methods on the physical and technical outputs of strikers during match play, thesis of master. Auckland University of Technology.

17- Metwally, A. J. (2013) : The Principles Of Biomechanics And Its Applications In The Field Of Sports, Mahi Publication And Distribution.

18- Pribadi. Y , Kontruksi (2005):

Tes Tembakan Penalti Dalam Permainan Hoki. Bandung: Universitas Pendidikan Indonesia.

19- Rikky. R, Angga M.(2018) :

Validity and Reliability of Penalty 
Stroke Tests in Hockey Games for Junior High School Students, Advances in Health Sciences Research, vol (11) ,154-156.

20-Shaalan .I and Abul-Majd. (2000): Soccer for modern juniors in the skillful, technical and tactical preparation, 500 practical training, Book Center for Publishing, Cairo..

21- Shirazi.J.E (1994): Hockey

umpire in the path of unified decisions, unpublished notes, hockey umpire training course, Egyptian Hockey Federation, Cairo.
22- Sofwan, N, Norasrudin, S, Redzuan, P, \& Mubin, A. (2012): Distinguishing Playing Pattern between Winning and Losing Field Hockey Team in Delhi FIH Road to London 2012 Tournament. Paper presented at the Proceedings of World Academy of Science, Engineering and Technology.

23- Wright, Mike, 2014: analysis of sporting rules- A survey," European Journal of Operational Research, Elsevier, vol. 232(1), pages 1-8.

- Website

24- http://www.fih.ch/en/fih/sport/ rules/hockey101 